\title{
PENGARUH MODEL PEMBELAJARAN TAKE AND GIVE TERHADAP PENINGKATAN KEMAMPUAN KOMUNIKASI MATEMATIKA SISWA
}

\section{Susti Rahmah Yulita $\mathbf{S}^{1}$, Ena Herlina ${ }^{2}$}

\begin{abstract}
The learning model that is applied is a learning model that provides an opportunity for students to construct their own knowledge, so that students are easier to understand the concepts taught and communicate their ideas in oral and written forms and provide space for students to interact with their friends to provide and receive and solve material in the learning process. This study aims to determine the effect of the use of take and give learning models on the improvement of mathematical communication skills of class VII MT MA Hunibera. The study was conducted using the quasi-experimental method, while the design used by the two groups posttest only design experiment. Sampling was done by cluster random sampling, class VII A as many as 30 students as the experimental class and class $B$ as many as 30 students as the control class. Because the data distribution is normal and homogeneous, the hypothesis used by the t-test, from the calculation results obtained $x^{2}$ count $=2,51$ and $x^{2}$ table $=$

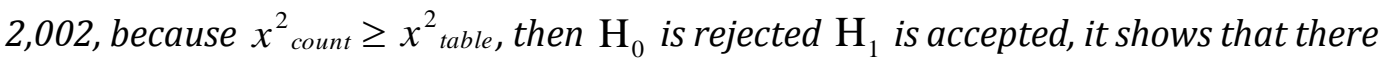
is an influence of the use of take and give learning models on improving mathematical communication skills students.
\end{abstract}

Keywords: Model of Taking and Giving Learning, Mathematical Communication

\begin{abstract}
ABSTRAK: Model pembelajaran yang diterapkan adalah model pembelajaran yang memberikan kesempatan kepada siswa untuk mengkonstruksi pengetahuannya sendiri, sehingga siswa lebih mudah untuk memahami konsep-konsep yang diajarkan dan mengkomunikasikan gagasan-gagasannya dalam bentuk lisan maupun tulisan serta memberikan ruang untuk siswa dalam berinteraksi dengan temannya untuk memberikan dan menerima serta memecahkan materi dalam proses pembelajaran. Penelitian ini bertujuan untuk mengetahui pengaruh penggunaan model pembelajaran take and give terhadap peningkatan kemampuan komunikasi matematika kelas VII MTs MA Hunibera. Penelitian dilakukan menggunakan metode kuasi eksperimen, sedangkan desain yang digunakan two grup posttest only design experiment. Pengambilan sampel dilakukan dengan cluster random sampling, kelas VII A sebanyak 30 siswa sebagai kelas eksperimen dan kelas B sebanyak 30 siswa sebagai kelas kontrol. Karena data distribusi normal dan homogen, maka hipotesis yang digunakan uji-t, dari hasil perhitungan diperoleh $x^{2}{ }_{\text {hitung }}=2,51$ dan $x_{\text {tabel }}^{2}=2,002$, karena $x_{\text {hitung }}^{2} \geq x_{\text {tabel }}^{2}$, maka $\mathrm{H}_{0}$ ditolak $\mathrm{H}_{1}$ diterima, hal tersebut menunjukan bahwa terdapat pengaruh penggunaan model pembelajaran take and give terhadap peningkatan kemampuan komunikasi matematika siswa.
\end{abstract}

Kata Kunci: Model Pembelajaran Take and Giving, Komunikasi Matematik

\footnotetext{
${ }^{1}$ Dosen Pendidikan Matematika, Universitas Mathla'ul Anwar Banten, Email: sustirahmah@ymail.com

${ }^{2}$ Mahasiswa Pendidikan Matematika, Universitas Mathla'ul Anwar, Email:

enaherlina@yahoo.com
} 


\section{PENDAHULUAN}

Salah satu disiplin ilmu pengetahuan yang memegang peran penting dalam kehidupan dan kehadirannya sangat terika erat dengan dunia pendidikan adalah matematika. Matematika perlu dipahami dan dikuasai semua lapisan masyarakat terutama siswa sekolah. Matematika berfungsi mengembangkan kemampuan menghitung, mengukur, menurunkan dan menggunakan rumus matematika yang diperlukan dalam kehidupan sehari-hari melalui pengukuran dan geometri, aljabar, peluang dan statistik, kalkulus dan trigonometri.

Menurut Hendriana dan Soemarmo (2014: 1) bahwa kata matematika berasal dari bahasa latin "mathemata" yang mempunyai arti "sesuatu yang dipelajari", sedangkan matematika yang pada bahasa Belanda disebut "wiskunde" yang mempunyai arti "ilmu pasti".

Matematika juga berfungsi mengembangkan kemampuan mengkomunikasikan gagasan melalui model matematika yang dapat berupa kalimat matematika dan persamaan matematika, diagram, grafik atau tabel. Tujuan umum pendidikan matematika ditekankan kepada siswa untuk memiliki: 1) Kemampuan yang berkaitan dengan matematika yang dapat digunakan dalam memecahkan masalah matematika, pelajaran lain ataupun masalah yang berkaitan dengan kehidupan nyata; 2) Kemampuan menggunakan matematika sebagai alat komunikasi.

Menurut Risnawati (2008: 24) bahwa kemampuan adalah kecakapan untuk melakukan suatu tugas khusus dalam kondisi yang telah ditentukan. Pada proses pembelajaran perolehan kemampuan merupakan tujuan dari pembelajaran. Kemampuan yang dimaksud adalah kemampuan yang telah dideskripsikan secara khusus dan dinyatakan dalam istilah-istilah tingkah laku. Kemampuan menggunakan matematika sebagai cara bernalar yang dapat dialihgunakan pada setiap keadaan, seperti berpikir kritis, berpikir logis, berpikir sistematis, bersifat objektif, bersifat jujur, bersifat disiplin dalam memandang dan menyelesaikan suatu masalah. Peningkatan kemampuan komunikasi siswa dapat dilakukan dengan mengadakan perubahan-perubahan dalam pembelajaran. Dalam hal ini, perlu dirancang suatu pembelajaran yang membiasakan siswa untuk mengkonstruksi sendiri pengetahuannya, sehingga siswa lebih memahami konsep yang diajarkan serta mampu mengkomunikasikan pemikirannya baik dengan guru, teman maupun terhadap materi matematika itu sendiri. Berkaitan dengan masalah tersebut maka komunikasi matematika siswa adalah kemampuan siswa untuk berkomunikasi yang meliputi penggunaan keahlian membaca, menulis, menyimak, menelaah, mendengar, berdiskusi, menginterprestasi, mengevaluasi gagasan, simbol, istilah serta informasi matematika.

Salah satu cara yang dapat dilakukan untuk meningkatkan pemahaman konsep dan kemampuan komunikasi matematika siswa adalah dengan menerapkan model pembelajaran yang relevan untuk diterapkan oleh guru. Menurut Sudjana (2005:76) bahwa metode pembelajaran ialah cara yang dipergunakan guru dalam mengadakan hubungan dengan siswa pada saat berlangsungnya pengajaran. Salah satu model pembelajaran yang bisa digunakan yaitu model pembelajaran take and give. Model pembelajaran take and give adalah model pembelajaran yang menekankan pada kegiatan memberi dan menerima informasi/pengetahuan yang diberikan oleh guru atau teman sebaya. Model pembelajaran take and give ini adalah satu dari sekian 
banyak model pembelajaran yang ada, yang bisa digunakan oleh seorang guru dalam meningkatkan kemampuan komunikasi siswa.

Menurut Lestari dan Yudhanegara (2015: 74) bahwa take and give adalah model pembelajaran yang menekankan pada kegiatan memberi dan menerima informasi. Tahapan pembelajarannya adalah: 1) Guru menyiapkan kartu yang berisi tentang materi yang harus dikuasai oleh siswa; 2) Setiap siswa mendapatkan kartu yang berisi submateri yang berbeda; 3 ) Setiap siswa mempelajari atau menghafal materi yang ada pada kartu yang didapatkannya; 4) Setiap siswa yang memberi dan yang menerima pengetahuan yang diperoleh dari kartu yang dimilikinya; dan 5) Guru mengarahkan siswa untuk membuat kesimpulan.

Menurut Huda (2014: 241) bahwa istilah take and give sering di artikan saling memberi dan saling menerima. Prinsip ini juga menjadi intisari dari model pembelajaran take and give. Take and give merupakan strategi yang di gunakan yan di dukung oleh penyajian data yang di awali dengan pemberian kartu kepada siswa. Di dalam kartu, ada catatan yang harus dikuasai atau dihafal masing-masing siswa. Siswa kemudian mencari pasanganya masing-masing untuk bertukar pengetauan sesuai dengan apa yang didapatnya di kartu, lalu kegiatan pembelajaran diakhiri dengan mengevaluasi siswa dengan menanyakan pengetahuan yang mereka miliki dan pengetahuan yang mereka terima dari pasangannya.

\section{METODE PENELITIAN}

Metode yang digunakan dalam penelitian ini adalah metode penelitian kuasi eksperimen. Metode penelitian kuasi eksperimen adalah suatu cara untuk mencari hubungan sebab akibat (hubungan kasual) antara dua faktor yang sengaja di timbulkan oleh peneliti dengan cara mengeliminasi atau mengurangi serta menyisihkan faktor-faktor lain yang bisa mengganggu. Sementara itu, metode eksperimen adalah suatu metode penelitian yang berusaha mencari hubungan variabel tertentu terhadap variabel lain dalam kondisi terkontrol secara ketat. Desain eksperimen menggunakan model two grup posttest only design experiment (Arikunto, 2010) yaitu eksperimen yang dilaksanakan pada dua kelompok yaitu kelompok eksperimen dan kelompok kontrol, dimana kelompok eksperimen dalam proses penelitian mendapatkan perlakuan dan postest tetapi pada kelas Kontrol hanya mendapatkan postest untuk lebih jelasnya dapat dilihat pada Tabel 1 berikut.

Tabel 1. Desain penelitian

\begin{tabular}{cccc}
\hline & Pretest & Treatmen & Posttest \\
\hline Eksperimen group & $\mathrm{T} 1$ & $\mathrm{X}$ & $\mathrm{T} 2$ \\
Kontrol group & $\mathrm{T} 1$ & 0 & $\mathrm{~T} 2$ \\
\hline
\end{tabular}

Arikunto, (2010)

Keterangan:

X : Perlakuan yang diberikan kepada kelas eksperimen berupa penggunaan model pembelajaran take and give

0 : Perlakuan yang diberikan kepada kelas kontrol berupa penggunaan pembelajaran konvensional

T1 : Nilai tes awal dari kelas kontrol dan eksperimen

T2 : Hasil belajar nilai tes akhir kelas kontrol dan eksperimen 


\section{HASIL DAN PEMBAHASAN}

Penelitian ini dilaksanakan di MTs MA Hunibera tahun pelajaran 2017/2018. Model pembelajaran yang digunakan dalam penelitian ini adalah model pembelajaran take and give yang diberikan pada kelas eksperimen dan model pembelajaran ceramah yang diberikan pada kelas kontrol. Berikut disajikan tabel distribusi frekuensi untuk data pretest kelas eksperimen seperti pada Tabel 2 berikut. Tabel 2. Tabel Distribusi Skor Pretest Kelas Eksperimen

\begin{tabular}{cccccccc}
\hline No & Kelas Interval & $\mathrm{F}$ & $\mathrm{X}_{\mathrm{i}}$ & $\mathrm{X}_{\mathrm{i}}{ }^{2}$ & $\mathrm{f} . \mathrm{X}_{\mathrm{i}}$ & $\mathrm{f.X}_{\mathrm{i}}{ }^{2}$ & $\begin{array}{c}\text { Frekuensi } \\
\text { Relatif }\end{array}$ \\
\hline 1 & $15-20$ & 4 & 17,5 & 306 & 70 & 1224 & $13 \%$ \\
2 & $21-25$ & 4 & 23 & 529 & 92 & 2116 & $13 \%$ \\
3 & $26-30$ & 5 & 28 & 784 & 140 & 3920 & $17 \%$ \\
4 & $31-35$ & 4 & 33 & 1089 & 132 & 4356 & $13 \%$ \\
5 & $36-40$ & 7 & 38 & 1444 & 266 & 10108 & $23 \%$ \\
6 & $40-49$ & 6 & 44,5 & 1980 & 267 & 11880 & $20 \%$ \\
& Jumlah & 30 & 184 & 6132 & 967 & 33604 & $100 \%$ \\
\hline
\end{tabular}

Jika persebaran data tersebut dikelompokan ke dalam bentuk diagram batang maka akan tampak seperti Gambar 1 berikut.

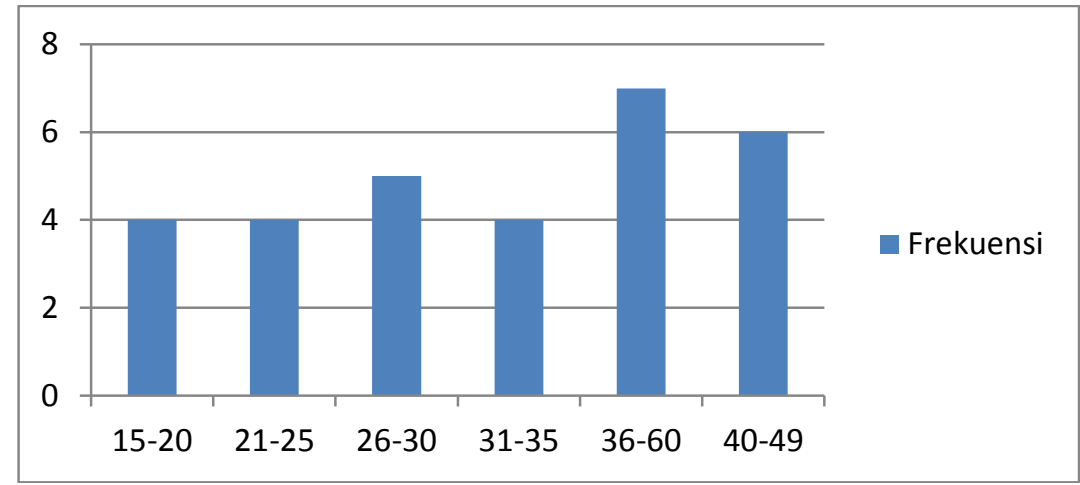

Gambar 1. Hasil Pretest Matematika Kelas Eksperimen

Berikut disajikan tabel distribusi frekuensi untuk data pretest kelas kontrol seperti pada Tebal 3 berikut.

Tabel 3. Distribusi Skor Pretest Kelas Kontrol

\begin{tabular}{cccccccc}
\hline & Kelas & & & & & \multicolumn{2}{c}{ Frekuensi } \\
No & Interval & $\mathrm{F}$ & $\mathrm{X}_{\mathrm{i}}$ & $\mathrm{X}_{\mathrm{i}}{ }^{2}$ & $\mathrm{f.X}_{\mathrm{i}}$ & $\mathrm{f.X}_{\mathrm{i}}{ }^{2}$ & Relatif \\
\hline 1 & $18-23$ & 3 & 20,5 & 421 & 62 & 1268 & $10 \%$ \\
2 & $24-28$ & 4 & 26 & 676 & 104 & 2704 & $13, \%$ \\
3 & $34-38$ & 5 & 36 & 1296 & 180 & 6480 & $17, \%$ \\
4 & $39-43$ & 7 & 41 & 1681 & 287 & 11760 & $23, \%$ \\
5 & $44-49$ & 6 & 48 & 2304 & 288 & 13824 & $20 \%$ \\
6 & $50-52$ & 5 & 44,5 & 1981 & 223 & 9905 & $17, \%$ \\
& Jumlah & 30 & 186 & 18359 & 1144 & 45941 & $100 \%$ \\
\hline
\end{tabular}


Jika persebaran data tersebut dikelompokan ke dalam bentuk diagram batang maka akan tampak seperti pada Gambar 2 berikut ini.

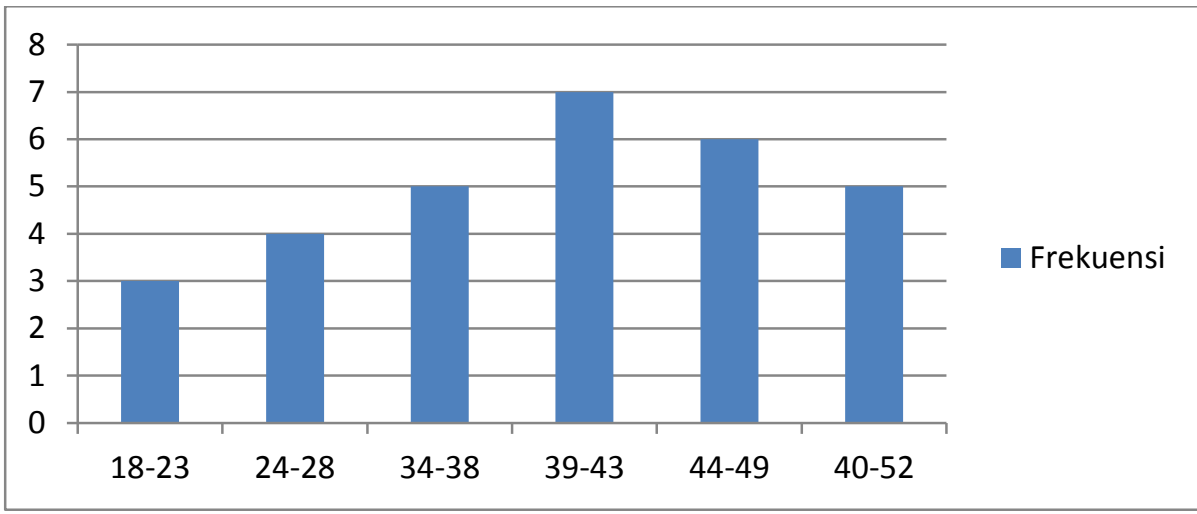

Gambar 2. Hasil Pretest Kelompok Kontrol

Distribusi frekuensi data kemampuan komunikasi matematika dengan menggunakan model pembelajaran take and give seperti pada Tabel 4 berikut.

Tabel 4.Tabel Distribusi Skor Posttest Kelas Eksperimen

\begin{tabular}{cccccccc}
\hline No & $\begin{array}{c}\text { Kelas } \\
\text { Interval }\end{array}$ & $\mathrm{F}$ & $\mathrm{X}_{\mathrm{i}}$ & $\mathrm{X}_{\mathrm{i}}{ }^{2}$ & $\mathrm{f} . \mathrm{X}_{\mathrm{i}}$ & ${\mathrm{f} . \mathrm{X}_{\mathrm{i}}{ }^{2}}$ & $\begin{array}{c}\text { Frekuensi } \\
\text { Relatif }\end{array}$ \\
\hline 1 & $40-55$ & 5 & 47,5 & 2256,25 & 237,5 & 11281,25 & $17 \%$ \\
2 & $56-62$ & 4 & 59 & 3481 & 236 & 13924 & $13 \%$ \\
3 & $63-69$ & 2 & 66 & 4356 & 132 & 8712 & $7 \%$ \\
4 & $70-77$ & 7 & 73,5 & 5402,25 & 514,5 & 37815,75 & $23 \%$ \\
5 & $78-84$ & 9 & 81 & 6561 & 729 & 59049 & $30 \%$ \\
6 & $85-90$ & 3 & 87,5 & 7656,25 & 262,5 & 22968,75 & $10 \%$ \\
& Jumlah & 30 & 414,5 & 23975,5 & 2111,5 & 153750,75 & \\
\hline
\end{tabular}

Persebaran data di atas dapat dilihat dalam grafik histogram dan poligon di seperti pada Gambar 3 berikut.

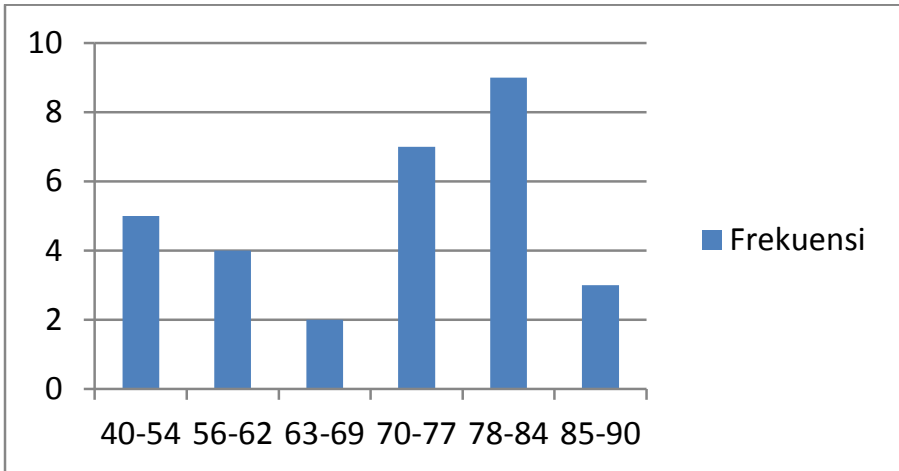

Gambar 3. Hasil Posttest Kelompok Eksperimen 
Berdasarkan hasil penyajian data dengan menggunakan tabel distribusi data yang telah dikelompokan di atas selanjutnya akan diberikan perbandingan terhadap mean sebelum dan sesudah diberikan perlakuan terhadap masing-masing kelas yang merupakan objek yang diteliti adalah sebagai berikut.

Tabel 5. Perbedaan Mean Kelas Eksperimen dan Kelas Kontrol

\begin{tabular}{cccc}
\hline Kelas & Pretest & Posttest & Perubahan hasil \\
\hline Eksperimen & 32,23 & 70,38 & 38,25 \\
Kontrol & 38,13 & 58,73 & 20,6 \\
\hline
\end{tabular}

Tabel 5 memberikan gambaran bahwa terjadi perubahan terhadap rerata baik terhadap kelas eksperimen maupun kelas kontrol. Perubahan yang besar terjadi pada kelas eksperimen yang diberikan perlakuan model pembelajaran take and give yaitu sebesar 38,25. Jika dibandingkan dengan kelas kontrol yang mengalami kenaikan 20,6. Perubahan pada kelas eksperimen itu sangat besar dan dapat dikatakan bahwa rata-rata nilai kemampuan komunikasi matematika pada kelas eksperimen setelah diberikan perlakuan menjadi 70,38 yang artinya rata-rata siswa pada kelas eksperimen memperoleh nilai 58,73 terhadap tes soal matematika pada pokok bahasan aljabar mengenai persamaan linier satu variabel dan pertidaksamaan linier satu variabel setelah diberikan perlakuan.

Pengujian normalitas kemampuan komunikasi matematika dengan menggunkan model pembelajaran take and give dan kemampuan kemampuan komunikasi matematika dengan menggunakan pembelajaran konvensional. Selain itu juga, di hitung uji homogenitas dan uji gain.

Uji normalitas data pretest kelas eksperimen menggunakan uji Chi kuadrat diperoleh nilai $X_{\text {hitung }}^{2}=4,481$, nilai tersebut $d k=k-3=6-3$ kemudian dibandingkan dengan nilai $X_{\text {tabel }}^{2}$ untuk $\alpha=0,05$, maka diperoleh $X_{\text {tabel }}^{2}=7,815$. Dengan membandingka $X_{\text {tabel }}^{2}$ dan $X_{\text {hitung }}^{2}$ diperoleh $X_{\text {tabel }}^{2}<X_{\text {hitung }}^{2}$ atau $4,48<$ 7,815 hal ini menunjukan data pretest kelas eksperimen berdistribusi normal.

Uji normalitas data pretest kelas kontrol menggunakan uji Chi kuadrat $\left(X^{2}\right)$ diperoleh nilai $X^{2}{ }_{\text {hitung }}=4,215$ nilai tersebut kemudian dibandingkan dengan nilai $X^{2}$ tabel untuk $\alpha=0,05$ dan $d k=k-3=6-3=3$ maka diperoleh $X_{\text {tabel }}^{2}=7,815$. Dengan membandingkan $X_{\text {tabel }}^{2}$ dan $X_{\text {hitung }}^{2}$ diiperoleh $X_{\text {tabel }}^{2}<X_{\text {hitung }}^{2}$ atau $7,815<4,215$, hal ini menunjukan data pretest kelas kontrol berdistribusi normal.

Uji normalitas data Posttest kelas kontrol menggunakan uji Chi kuadrat $\left(X^{2}\right)$ diperoleh nilai $X^{2}{ }_{\text {hitung }}=6,41$ nilai tersebut kemudian dibandingkan dengan nilai $X_{\text {tabel }}^{2}$ untuk $\alpha=0,05$ dan $d k=k-3=6-3=3$ maka diperoleh $X_{\text {tabel }}^{2}=7,815$. Dengan membandingkan $X_{\text {tabel }}^{2}$ dan $X_{\text {hitung }}^{2}$ diperoleh $\quad X_{\text {tabel }}^{2}<X^{2}{ }_{\text {hitung }}$ atau $7,815<6,41$, hal ini menunjukan data pretest kelas kontrol berdistribusi normal.

Uji normalitas data Posttest kelas kontrol menggunakan uji Chi kuadrat $\left(X^{2}\right)$ diperoleh nilai $X_{\text {hitung }}^{2}=2,06$ nilai tersebut kemudian dibandingkan dengan nilai $X_{\text {tabel }}^{2}$ untuk $\alpha=0,05$ dan $d k=k-3=6-3=3$, maka diperoleh $X_{\text {tabel }}^{2}=7,815$. 
Dengan membandingkan $X_{\text {tabel }}^{2}$ dan $X_{\text {hitung }}^{2}$ diperoleh $\quad X_{\text {tabel }}^{2}<X_{\text {hitung }}^{2}$ atau $7,815<2,06$, hal ini menunjukan data pretest kelas kontrol berdistribusi normal.

Berdasarkan hasil perhitungan diperoleh $F_{\text {hitung }}$ sebesar 1,03. Pada $F_{\text {tabel }}$ dengan $\mathrm{db}_{\text {pembilang }}$ yaitu 29 dan $\mathrm{db}_{\text {penyebut }}$ yaitu 29 pada taraf signifikan 0,05 diperoleh nilai $F_{\text {tabel }}=1,85$ dengan demikian berarti $F_{\text {hitung }} 1,03 \leq F_{\text {tabel }} 1,85$ maka kedua jenis data homogen.

Berdasarkan hasil perhitungan diperoleh $F_{\text {hitung }}$ sebesar 1,56. Pada $F_{\text {tabel }}$ dengan $\mathrm{db}_{\text {pembilang }}$ yaitu 29 dan $\mathrm{db}_{\text {penyebut }}$ yaitu 29 pada taraf signifikan 0,05 diperoleh nilai $F_{\text {tabel }}=1,85$ dengan demikian berarti $F_{\text {hitung }} \leq F_{\text {tabel }}$ maka kedua jenis data homogen.

Berdasarkan hasil uji gain ternormalisasi data kelas eksperimen menunjukan bahwa interpretasinya bervariatif yakni kategori sedang sebanyak 25 siswa dan kategori tinggi sebanyak 5 siswa seperti pada Tabel 6 berikut.

\begin{tabular}{ccc}
\multicolumn{3}{c}{ Tabel 6. Mean Gain Kelas Eksperimen dan Kelas Kontrol } \\
\hline Kelas Eksperimen & Kelas Kontrol & Perubahan Hasil \\
\hline 0,46 & 0,36 & 0,10 \\
\hline
\end{tabular}

Tabel 6 memberikan gambaran bahwa terjadi perubahan terhadap kelas rerata eksperimen yang diberikan perlakuan dengan menggunakan model pembelajaran take and give dibandingkan dengan kelas kontrol.

Berdasarkan hasil analisis data dengan uji-t diperoleh harga $t_{\text {hitung }}$ 2,51 dan harga $t_{\text {tabel }}$ dengan taraf signifikan $5 \%$ dan dk $=30+30-2=58$ maka diperoleh $t_{\text {tabel }}$ $=2,002$. Maka hipotesis nol ditolak yang berarti hipotesis kerja $\left(\mathrm{H}_{1}\right)$ diterima, yaitu terdapat perbedaan peningkatan kemampuan komunikasi matematika siswa yang menggunakan model pembelajaran take and give dengan siswa yang menggunakan pembelajaran konvensional.

\section{KESIMPULAN}

Hasil analisis data secara perhitungan statistik dapat disimpulkan bahwa model pembelajaran take and give berpengaruh terhadap kemampuan komunikasi matematika siswa kelas VII MTs Hunibera tahun pelajaran 2017/2018. Hal itu di tunjukan oleh data hasil analisis dengan menggunakan rumus $u j i-t$, diperoleh $t_{\text {hitung }}$ 2,23 dan $t_{\text {tabel }}$ untuk tarif signifikan 0,05 dengan derajat kebebasan 50 di peroleh $t_{\text {tabel }}$ sebesar 2,01. Hasil perhitungan diperoleh hasil $t_{\text {hitung }}>t_{\text {tabel, }}$, sehingga hipotesis Ho di tolak dan (H1) diterima. Dengan demikian berarti model pembelajaran take and give bepengaruh terhadap peningkatan kemampuan komunikasi matematika siswa kelas VII MTs Hunibera tahun pelajaran2017/2018.

Dari hasil data terlihat bahwa siswa yang proses pembelajarannya menggunakan model pembelajaran take and give memiliki skor nilai yang lebih tinggi dibandingkan dengan siswa yang menggunakan pembelajaran konvensional. Khususnya pada pokok bahasan persamaan linier satu variable dan pertidaksamaan linier satu variabel, siswa harus diberikan model pembelajaran yang mengharuskan siswa untuk aktif, dan kreatif. Dengan kata lain kalau penggunaaan model pembelajaran yang diberikan tepat, maka siswa akan mampu menguasai matematika dengan baik .. 


\section{DAFTAR PUSTAKA}

Arikunto, S. (2010). Prosedur Penelitian. Jakarta: Rineka Cipta.

Hendriana, H., \& Soemarmo, U. (2014). Penilaian Pembelajaran Matematika. Bandung: Refika Aditama.

Huda, M. (2014). Model-model Pengajaran dan Pembelajaran. Yogyakarta: Pustaka pelajar.

Lestari, E. K., \& Yudhanegara, R. M. (2015). Penelitian Pendidikan Matematika. Bandung: Refika Aditama.

Risnawati. (2008). Pembelajaran Matematika. Pekanbaru: Suska Press.

Sudjana, N. (2005). Penilaian Hasil Proses Belajar. Bandung: Remaja Rosdakarya. 